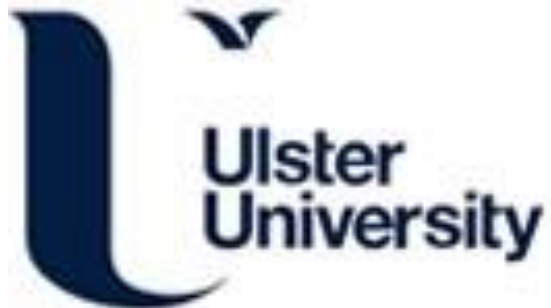

\section{The measures and materiality of Improvement in Ireland}

Forsythe, W. (2013). The measures and materiality of Improvement in Ireland. International Journal of Historical Archaeology, 17(1), 72-93. https://doi.org/10.1007/s10761-012-0214-x

Link to publication record in Ulster University Research Portal

\section{Published in:}

International Journal of Historical Archaeology

Publication Status:

Published (in print/issue): 01/01/2013

DOI:

10.1007/s10761-012-0214-x

\section{Document Version}

Publisher's PDF, also known as Version of record

\section{General rights}

Copyright for the publications made accessible via Ulster University's Research Portal is retained by the author(s) and / or other copyright owners and it is a condition of accessing these publications that users recognise and abide by the legal requirements associated with these rights.

\section{Take down policy}

The Research Portal is Ulster University's institutional repository that provides access to Ulster's research outputs. Every effort has been made to ensure that content in the Research Portal does not infringe any person's rights, or applicable UK laws. If you discover content in the Research Portal that you believe breaches copyright or violates any law, please contact pure-support@ulster.ac.uk. 


\title{
The Measures and Materiality of Improvement in Ireland
}

\author{
W. Forsythe
}

Published online: 11 January 2013

(C) Springer Science+Business Media New York 2013

\begin{abstract}
This paper examines the impact and evidence of Improvement thinking on domestic and social spheres. Taking the example of Ireland it examines the origin and development of improving strategies and methodologies from the seventeenth to nineteenth centuries, in particular the widening application of reform to incorporate domestic, educational and moral concerns. Improvement measures were imposed on communities often by a land-owning class of differing social and religious origin, engendering socio-political tension still evident in Ireland today. Equally it was a period of new commercial opportunities and social betterment creating new class divisions that have been previously undervalued. This paper draws on work on a group of islands on the northern periphery of the country, where archaeological and historical evidence demonstrate that the reforms associated with the Improvement project were still underway well into the nineteenth century.
\end{abstract}

Keywords Improvement·Domestic $\cdot$ Ireland $\cdot$ Consumerism

\section{Introduction}

Archaeologists concerned with economic and social development in the historic era have commonly turned to capitalism as a convenient framework to examine changing practice. This has provided a link between material culture and ideology, consumerism, labor relations, power and resistance. One of the most important discourses underpinning new forms of capitalism in Ireland and Britain was that of Improvement. The concept of Improvement functioned originally as a financial creed to advance the fortunes of the nation and thereby raise the living standards of its inhabitants. By following rational, Enlightenment principals, trade and prosperity would flow, habits and morals would be reformed and the nation modernized. Some

\footnotetext{
W. Forsythe $(\square)$

Centre for Maritime Archaeology, School of Environmental Sciences, University of Ulster, Coleraine, BT52 1SA Co. Derry, Northern Ireland

e-mail: w.forsythe@ulster.ac.uk
} 
origins of Improvement as a post-medieval concept with applications to Ireland have been summarized by Orser (2005a, pp. 394-395) who highlighted individuals such as Francis Bacon and John Locke. They explicitly linked an ordered and well-managed landscape with "civility," and suggested that it was capable of having a civilizing influence on the populace. Locke went on to justify the confiscation of land from those who neglected to improve it to an English standard, thus validating British imperialism in North America and Ireland (Wood 2002, pp. 110-115). Sir John Davies had also touched on this justification for seizing Ireland in the early seventeenth century. Linking it to a strong sense of Christian (i.e., Protestant) policy and destiny he suggested that improvers were adding to the country rather than taking it away from its irresponsible inhabitants (Wood 2002, pp. 159-160). Likewise in 1652, the English are described as the "introducers of all good things in Ireland for which that brutish nation...hath rewarded them with unthankfulness, hatred and envy" (Boate 1726, p. 64). In this sense the ethos of Improvement neatly dovetailed with both the English historical narrative of their involvement in Ireland and justified their future plans and ambitions (see e.g., Barnard 2008).

By the end of the seventeenth century the creed of Improvement was principally concerned with agricultural reforms, including reclamation of "waste" land and enclosure of field systems. This process also involved the elimination of customary practices with real impacts on the lives and routines of ordinary people e.g. the erosion of rights and access to land held in common. Indigenous practices, although well established and providing clear precedents were now viewed as backward (Wood 2002, p. 107; Tarlow 2007, p. 17). In the eighteenth and nineteenth centuries, the scope of Improvement was widened to embrace social and moral transformation aimed at eliminating poverty, moral rehabilitation and educating the populace. Institutions such as schools, libraries, prisons, workhouses, and hospitals gave physical form to moral imperative. The result would be a citizenry conforming to civilized standards producing peace and prosperity for an Ireland fully assimilated into the British family. In effecting behavioral reform, the drive for improvement would necessarily touch on the domestic sphere-e.g., standards of hygiene in the home and propriety in manners. The imposition in Ireland on cultural and moral worlds was at once intimate and volatile. The nature of Irish governance meant that the ruling class was separated from the majority not only by origins, wealth, and status but also religion and often language (Busteed 2001, p. 327). The religious differences in particular would dominate social status, cultural attitudes, and political discourse in a way never achieved by class divisions. This deep schism in Irish society has also largely shaped the approach of archaeologists to understanding the country; however, the emergence of class distinctions is an important development within the historic era and one deserving of more recognition.

\section{Genealogies for Improvement in Ireland}

Elements of domestic and other reforms urged by Improvement can be traced to earlier eras in Britain. Johnson $(1996,1997)$ has examined traits of market capitalism in England in the sixteenth century, including improvement measures later given parliamentary backing such as the enclosure of fields from the Late Medieval period. 
New patterns of consumption and domestic routines were also emerging such as an increased concern with furnishings, tableware and segregated eating and living spaces. In the sixteenth century, this was primarily an urban phenomenon, parts of the countryside would not display similar changes for almost 200 years (Johnson 1996, p. 201). Further north, enclosure was underway in the Scottish lowlands by the seventeenth century, becoming more widespread after 1760 (Dalglish 2003). Aspects of Scottish domestic change in the eighteenth and nineteenth centuries mirror Irish reforms. They included a change of building materials (stone and lime walling as opposed to clay walls), roofing tiles and internal subdivision (Dalglish 2003, pp. 141-147).

Proudfoot (1993, p. 224) has noted that the nascent capitalism present in sixteenthcentury England was also present in both Old English and Gaelic controlled parts of Ireland (e.g., Kilkenny and Galway). This development was arrested in the late sixteenth and early seventeenth century with the Tudor reconquest and subsequent large-scale confiscations of native lands to English and Scottish settlers. The aims, pace and nature of change would now be set by English thinking on cultivation, science, commerce, manners, habits, and religion. After further conflict in the midseventeenth century, the British began a process of enclosure and reclamation on their estates with varying degrees of success. Progress was uneven and slow and blame was leveled at the intractable natives as well as the landowners (Barnard 2008, pp. 14-15). William Petty's large estate around Kenmare in Co. Kerry was one such example (Barnard 1981, 1982). Petty surveyed his lands for resources and agricultural potential, eventually reclaiming and draining land. He established the new town of Kenmare and with an iron works and fishery, built the first pier in the county and improved the roads. To obtain the skills he needed he introduced English craftsmen. The project was not a success for a number of reasons including Petty's absence, incompetent subordinates, lack of finance, a lack of investigation into the suitability of local ores and a failure to consider issues of the market and transport costs (Barnard 1982; Wood 1934; Andrews 1956). In a number of aspects concerning the establishment and fate of the endeavor there are striking parallels with Burton Conyngham's Rutland a century later (see below). The political upheavals of the 1680s put an end to Petty's project and by the end of a turbulent century the progress of Improvement had stalled. The relative peace of the eighteenth century provided an opportunity to reinvigorate efforts.

By the eighteenth century, the doctrine of cosmopolitan progress and Improvement was firmly in place and advocated by political economists as moral and necessary (Drayton 2000, p. 55). The early eighteenth century saw the consolidation in Ireland of the "Protestant Ascendancy" and its parliament, and with it a new patriotism expressed in a desire to see Ireland prosper both materially and culturally. There was nevertheless a degree of conflict on the part of an ascendancy wanting to see the Irish people improved whilst maintaining cultural and political superiority over the majority Catholic population. This ambivalence was also displayed toward the British. On one hand there was irritation at Ireland's obviously dependant position and particular frustration at the restrictions on Irish trade. At the same time the ascendancy was reminded of its reliance on Britain in times of strife and was overwhelming Anglophone in its tastes from fashion to architecture (Barnard 2001). Moral and social improvement became increasingly visible in the eighteenth century through the activities of landowning clergy and their involvement in 
improving societies (Barnard 1995; Busteed 2001, p. 326). The religious influence (i.e., Protestant) was promoted through emergent institutions such as schools, libraries, and workhouses, which focused on individual discipline and productivity. The resulting individualistic capitalist ethic blurred the boundaries of economic and moral improvement (Livesey 2004, p. 635). The main agents of Improvement in eighteenthand nineteenth-century Ireland were landlords, government, improving societies, clergy, and the tenants themselves.

The intellectual community was a crucial promoter of Improvement ideas. Scientific inquiry carried out by figures such as Gerard and Arnold Boate inspired William Molyneaux to found the Dublin Philosophical Society (1683-1708) (Barnard 1975). Early improvers urged the reading of English treatises on agriculture but Irish texts on the subject also appear. Other individuals such as Arthur Young would have a profound affect on encouraging agricultural changes in the 1770s. In urban life key advocates for modernizing were the improving societies. The Dublin Society for the Improvement of Natural Knowledge, Mathematics, and Mechanics closed during the 1690s but was reconstituted in 1731 as the Dublin Society for the Improvement of Husbandry and Manufactures, and other Useful Arts and Sciences, becoming the Royal Dublin Society in 1750. The reformed Society had an increased emphasis on the economic development of the country, especially through agriculture. In an era of Irish political restriction and dependency the improving societies mimicked the activities of the state, although they had too few parliamentarians among their ranks to be pivotal (Livesey 2004, p. 616; Magennis 2002, p. 202). A key aim of the Physico-Historical Society (founded 1744), was to reveal the extent of Improvement since the seventeenth century and repudiate the association of Ireland with ignorance (Magennis 2002, p. 200). The societies sponsored a number of ways to advance Improvement, from a scheme of prizes for endeavors in agriculture and kelp and salt making, to the establishment of agricultural schools (Bell and Watson 1986, p. 5; Ludlow 1989, p. 8; Ramsay 1918, p. 59). They also funded statistical surveys on the state of agriculture on a county basis, including McParlan's for Donegal (1802) and Dubordieu's for Antrim (1812). Ultimately, although the societies undoubtedly enriched cultural life in the city, their schemes had little impact on the poor, illiterate population of the countryside.

In the eighteenth century, government introduced a number of legislative measures to stimulate the market economy, although their effectiveness was blunted by British trade restrictions on Ireland. Schemes funded by the Irish House of Commons included the construction of canals such as Newry and Dublin (Dickson 1987, p. 108). They also introduced a number of legislative measures to encourage reclamation (Feehan and O'Donovan 1996, pp. 41-42). After the Union of 1801 and the economic downturn of 1815, government took a more direct role, largely under the auspices of the Board of Public Works. Between 1832 and 1881 they spent $£ 33$ million on grants and loans. The money was invested in infrastructure, public buildings and institutions. Although legislative reform was slow, agricultural projects such as land reclamation were financed, e.g. in Donegal the arable land increased in the 1840 s from $600 \mathrm{~m}^{2}\left(155,399 \mathrm{ha}^{2}\right)$ to over a million (Census of Ireland 1851, $\mathrm{p}$. xiii; Feehan and O'Donovan 1996, p. 57).

Those with most ability to effect Improvement for much of the period were arguably the landowners. Landlords had the resources to undertake widespread 
landscape change, inevitably affecting the lives of their tenants. Irish landlords have long suffered a poor reputation, reinforced by folklore, historical accounts, and contemporary reports (Bell and Watson 1986, p. 4). They are regarded as fostering an exploitative, extractive economy, with little regard for their tenants' welfare and high levels of absenteeism from their estates. This generalized view fails to take account of variation in their means, ability, and interest in their holdings (see Busteed 2001, p. 319; Ó Gráda 1994, p. 123; Proudfoot 1993). In the seventeenth and early eighteenth centuries in particular, Irish landlords faced significant challenges including transport, resources, and an under-developed manufacturing sector. Yet in the late eighteenth, the Irish economy grew and rents increased freeing capital to re-invest in their holdings. Beyond improving their houses and demesnes there was a general reluctance to fund agricultural and industrial schemes (Ó Gráda 1994, p. 123). By the early nineteenth century, the economy slowed and the opportunity passed, cruelly exposing the weakness of re-investment.

Final agents in progressing Improvement were the tenants themselves. Inevitably this rarely occurred on a large scale and modest agricultural measures were undertaken by the relatively better-off lowland farmers (Dickson 1987, pp. 115-116; Ó Gráda 1994, p. 31). In some cases tenants were required by the terms of their leases to undertake improvement work. In one case from Co. Tyrone in 1783, the tenant was expected to erect enclosures, plant an orchard, and maintain all buildings (Crawford and Trainor 1978, pp. 13-17). An expectation to improve dwellings and farm buildings was also the case in Donegal (Devon Commission 1847, p. 131). Tenants in the north also had the advantage of the "Ulster Custom," whereby departing tenants extracted a payment from those succeeding them-this was in effect a compensation for improvements made to their farm. Being a custom rather than a legal right however, it was not universally observed (Dowling 1999). The expanding economy of the eighteenth century allowed tenants of some means the opportunity to improve their social station and the emergence of a "middling class" is one of the crucial social developments of the century (Cullen 1990, pp. 61-63; Wall 1989). However, the tendency for landlords to increase the rents on holdings now deemed superior may have held the inclination to display their modest means in check.

\section{Improving the Islands}

The islands of Ireland's north, west and southern fringes present an opportunity to examine the processes and consequences of Improvement in areas remote from urban centers and agriculturally rich parts of the country. As such, reforms associated with agricultural improvement (e.g., reclamation and drainage) can be detected as an ongoing process late into the nineteenth century. On the other hand, remnants of traditional practices also survived more universal reforms carried out elsewhere. The islands under examination are located off north and west Ulster and include Rathlin, Co. Antrim, and a group of islands in The Rosses district of west Donegal, in particular Rutland Island (Fig. 1). Although these islands had varied experience of economic reform under different landowners, all of them saw attempts to modernize agriculture, infrastructure, buildings and services. In addition ideas of moral and social development also had an impact on island societies. 


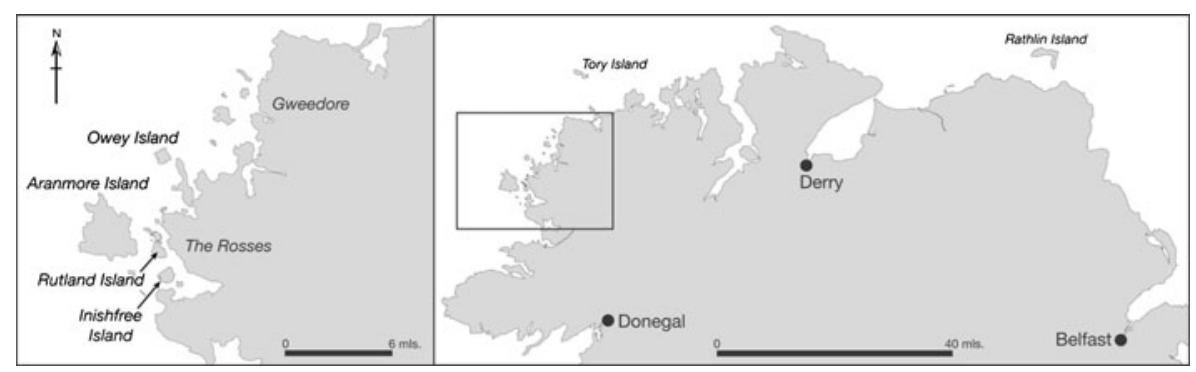

Fig. 1 Map of the north of Ireland and islands involved in the study

The Rosses islands were part of a large coastal area confiscated in the early seventeenth century and transferred to Scottish planters. Regarded as peripheral, agriculturally poor and relatively inaccessible, the property was let to successive leaseholders who collected rents and royalties without investment. By the late eighteenth century the district was the property of William Burton Conyngham (1733-96). A keen reformer and antiquarian, Conyngham owned estates in counties Meath and other parts of Donegal. As a Member of the Irish Parliament, he also exercised influence on affairs of state and enterprise (Kelly 1985; Trench 1985). Conyngham was keen to make his Donegal property more productive and saw his opportunity in the huge shoals of herring visiting the Donegal coast annually. Local fishermen had been active in harvesting this resource but were impeded by having limited facilities to preserve, pack and transport the fish. Much of the catch went to waste and locals resorted to manuring the fields with it. In response, Conyngham embarked on one of the most ambitious schemes of eighteenth-century Ireland-the establishment of an entirely new town with all the facilities required for processing and exporting the catch as well as the servicing needs of ships, equipment and men (for similar planned settlements in Ireland see Jupp 1970; Kelly 1986; Longfield 1967). He chose the small island of Inismacanduirn (renamed Rutland in honor of the Lord Lieutenant) and construction work began in 1783. The complex included quaysides, stores, saltworks, ship-building yard, forge, pattern house, inn, and a customs house (Forsythe 2012).

The island of Rathlin had been in the possession of the Scottish Lords of the Isles since the Medieval period (Forsythe and McConkey 2012). Their descendants, the McDonnells, had been remarkably successful in holding on to their possessions in Ireland despite being Catholic. Nevertheless, by the mid-eighteenth century the profligate fifth Earl of Antrim was forced to sell the island to settle debts. In 1746, the Rev. John Gage purchased a long leasehold on the property and set about modernizing his interest. As an Anglican clergyman, Gage was a member of the established church in Ireland. In contrast to Conyngham, Rathlin was his only property and was his only residence after ca.1760. Furthermore, he lacked the political weight of his Donegal counterpart-his petition of 1758 for the improvement of harbors on the island was rejected by Parliament. Conyngham, on the other hand, secured $£ 20,000$ from the Irish parliament for his Rutland scheme.

A number of conventional elements of Improvement were undertaken by Gage, Conyngham and their successors in the eighteenth and nineteenth centuries. These included gradual drainage, reclamation and enclosure of new fields, road and 
communications upgrading, and some experimentation with new crops. A number of these on-going landscape changes can be detected on the first detailed maps of Ireland (Ordnance Survey) dating to the 1830s and revised in the 1850s. Islanders took advantage of their maritime location to collect seaweed for use as fertilizer and shells for burning to produce lime for fields and construction. Liming the soil using local chalk (e.g., Rathlin) or shelly sand and shells was advantageous in wet, acidic areas. Burning lime in rough kilns was known on the islands (there are examples on Aranmore and Tory, see also Mason 1936, plate 19). More formal lime kilns were increasingly common from the mid-eighteenth century (Bell and Watson 1986, p. 35) and there are examples on Rutland and Rathlin. Arthur Young, the noted advocate for agricultural reform, singled out the production of lime in numerous kilns around Ireland as a particularly successful aspect of Irish Improvement (Hutton 1892, pp. 93-95).

Reform of tenant landholdings and farms had direct implication for traditional land management practices and settlement. Periodic redistribution of holdings among tenant farmers (rundale practice) ensured variation in the quality of arable and grazing land (McCourt 1954, 1955). Of prime importance to tenants in the rundale system was equality of landholding, both in extent and quality. Rundale farmers had access to two principal agricultural areas: the arable infield and a larger, enclosed area used for pasture and periodic cultivation known as the outfield. There was also common meadow, upland grazing (often with peat-bog) and small, enclosed gardens near the settlement (Buchanan 1973, p. 586). The system also extended to the seashore, dividing sections of the coast for seaweed collection rights. This constantly changing arrangement caused difficulties for landlords attempting to assess holdings for rental value over longer terms. Ideally, they sought to assign each tenant to a portion of land for the entire term of their leases and to have each tenant living on or adjacent to their holding. One compromise reached with regard to holdings were ladder fields - plots divided into long strips incorporating shore, arable fields, and mountain grazing, thus preserving tenants' concern for varied land and resources (Hill 1971).

Much island agriculture continued to concentrate on the potato, despite calls to broaden the basis of subsistence and experiment with new crops. The great advantage of potatoes was their ability to thrive in poor, marginal conditions. Grown in cultivation ridges known as "lazy beds," they were commonly viewed by improvers as evidence of the backward nature of Irish agriculture (Bell and Watson 1986, p. 23). It was complained that furrows (making up one-half to one-third of the cultivated area) were a waste and that the rounded ridges shaded some of the plants, hindering growth. A central advantage of the ridges was their function in drainage. In reclaiming land, ridges, and through-drainage increased efficiency by complementary orientation to each other, although the need for them was diminished after the land was successfully broken in (Bell and Watson 1986, pp. 24-26). Arthur Young had to concede that some aspects of Irish agriculture worked well and his tallies of grain and potato yields compare favorably with other European countries (Ó Gráda 1994, p. 25). By the nineteenth century, the suitability of Irish methods to the local environment was acknowledged by a few (e.g., Bell 1984, pp. 90-94; Lambert 1845). If managed well the old rotations could be successful, particularly where there was access to seaweed, sand and lime (Feehan 2003, pp. 98, 115).

Other aspects of agricultural and maritime activity would draw islanders into the wider commercial world and have repercussions for islanders' ability to effect change to 
their domestic surroundings. The eighteenth century saw the emergence of a burgeoning linen industry in Ulster and islanders were devoting part of their landholdings to growing flax as well as foodstuffs. A crucial component of their contribution was burning seaweed to produce kelp (Forsythe 2006). The kelp, or soda ash, was an important alkali used for bleaching textiles. For the islanders it represented an important cash crop, which in 1784 paid the entire rent for the island of Rathlin (Hamilton 1839).

\section{Domestic Life Under Improvement}

Although landlords rarely interfered with the internal arrangements of the home, they did have preferences for the type and location of settlement their tenants inhabited. Along the northern and western seaboards many communities lived in nucleated settlements known as "clachans" (Proudfoot 1959). These small clusters of dwellings lacked any formal economic or social infrastructure one would find in a village - shop, post office, or church. The origins of the clachan settlements are unclear. Some authors (e.g., Evans 1977) have reached as far as the Early Medieval period; more recently it has been argued that many western districts with intense clachan concentration were a product of eighteenth-century population migration and economic adaptation (Whelan 1995, 1997). McCourt (1973) has stressed the essentially fluctuating nature of Irish settlement with single dispersed farms and kin-group clustered settlement re-occurring over centuries. In the historic period, there is seventeenth-century evidence of both single, compact farms, and small clachans co-existing (e.g., Limavady, Co. Derry), and by the mid-nineteenth century there are cases of both types having evolved to small rundale holdings (Proudfoot 1959, p. 116; McCourt 1971, p. 131). Some of the earliest evidence from estate maps has indicated that joint-leasing to small partnerships were common. These were not always kin-groups but often developed as such, and were common in western counties such as Donegal (McCourt 1971, p. 133). The growth of clachans was slow until the end of eighteenth century due to a smaller population and the availability of large areas of un-reclaimed lands capable of absorbing any increased demographic pressure (McCourt 1971, p. 135). In the first quarter of the nineteenth century agriculture and population expanded rapidly, as did the clachans. Conversely, after the Great Famine of the 1840s the reduction in population and increased land consolidation saw many clachans abandoned (Proudfoot 1959, p. 116). Those that survive in areas such as the islands predominantly date to the eighteenth-nineteenth centuries. As noted above, part of the ambition for land reform involved the removal of tenants' homes so land could be worked more efficiently by "placing each tenant's house upon his own ground...enabling them to place their dwellings, offices, and manure heaps in the most convenient situation for comfort and cleanliness" (Hill 1971, p. 45). In the 1840s, Donegal landlord George Hill (1971, p. 25) argued that the clusters of houses allowed disease to spread and gave rise to quarrelling among neighbors. The breakup of the clachan involved a substantial degree of social upheaval and islanders lamented the loss of community and close social contact (MacSuibhne 1995). For this reason encouragement to relocate was vigorously resisted and without the landowner actually providing new, improved accommodation there was little incentive (or means) to move.

One exemplar of domestic conditions for islanders was the residences that the landlords built for workers they hoped to attract, on Rathlin the Gages attempted to 
establish skilled weavers from the mainland, and in Rutland a range of farmers, fishermen, and craftsmen were required for the new town. The resulting houses introduced new modes of architecture and materials into the islands. An article in the Dublin Evening Post (1785) provides insight into the trades and skills Conyngham required for his Rutland fishing settlement: "merchants, boat-builders, sailmakers, rope-makers, coopers employed in fishery...masons, carpenters, smiths, slators and other persons employed in building." Attractive terms are offered to settlers, "he will give a lease in perpetuity... at a reasonable rent, and for every $100 \mathrm{lb}$ expended in permanent improvements, the person... shall receive $50 \mathrm{lb}$, without deduction of interest." Conyngham's generosity was occasioned by the belief that the scale of his enterprise and expertise needed was beyond that which could be found in the locality among his "ignorant and indolent tenantry" (PRONI T/3469/9). He hoped to attract farmers from the wet moors of England to improve the agricultural potential of the district; and appealed to "loyal Americans" accustomed to fisheries or any commerce (again offering attractive leases, PRONI T/3469/9; Trench 1985, p. 56). Although Burton Conyngham's attempts to attract outsiders to the settlement are generally believed to have been unsuccessful (see e.g., Kelly 1985) he did attract some British families, as well as men from the Dublin area (Ua Cnaímhsí 2000, p. 53).

The residential houses on Rutland Island were erected to the south of the fishing station, and remain a striking and incongruous element of the landscape to this day. They comprise a terraced street, originally known as "Tarant Street" (after Burton Conyngham's companion, Col. Tarant). To small tenants the upper floor on these buildings (and the Rathlin example below) would have been unknown in rural eighteenth-century Ireland, and only became fashionable in vernacular houses from the mid-nineteenth century. Collectively, the Rutland buildings were described as "of a superior description to what then existed" (Fourth Report of the Commissioners of the Irish Fisheries 1823, p. 26). According to contemporary surveys of the island (McGarrigle collection; Trench 1985 , p. 50) the residential street was to extend further east and be one of three adjacent streets, the others (Granby Row and Welles Street) were never constructed. It was described in 1812 as a street of 15 small houses (NLI Ms35, 392/4).

Tarant Street is some $52 \mathrm{~m}$ long and $8.3 \mathrm{~m}$ wide with 16 houses in total. The houses were built at the same time - the north and south walls (i.e., the front and back of each row) are one continuous build. The building material is granite blocks, with larger granite corner quoins at the ends of the terrace. They are identical, with three square windows $(0.85 \times 0.85 \mathrm{~m})$ on the upper floor, two rectangular ones $(0.86 \times$ $1.20 \mathrm{~m}$ ) on either side of the centrally placed ground floor door (Fig. 2). There are segmental granite lintels over external windows (with limestone sills) and doorsinternally this is red brick. Both windows and doors feature recesses in the molding to accommodate a wooden frame. The interior flooring is shale slabs. The chimney flues are set back-to-back and the houses have slate roofs set on a slate lining at the wallhead. To the rear of the houses were individual garden plots and these allowed surface collection of a range of ceramics and glassware (see below). Additional pictorial evidence is provided by the fine elevation and plan of the north row in the National Library ("A plan of eight houses comprising the entire range on the north side of Tarrant Street in the Island of Rutland in the county of Donegal with garden attached to them" NLI Ms 35,401/3; Fig. 3). This shows the rendered walls and slate roofs, 
Fig. 2 Tarant Street house frontage, Rutland Island
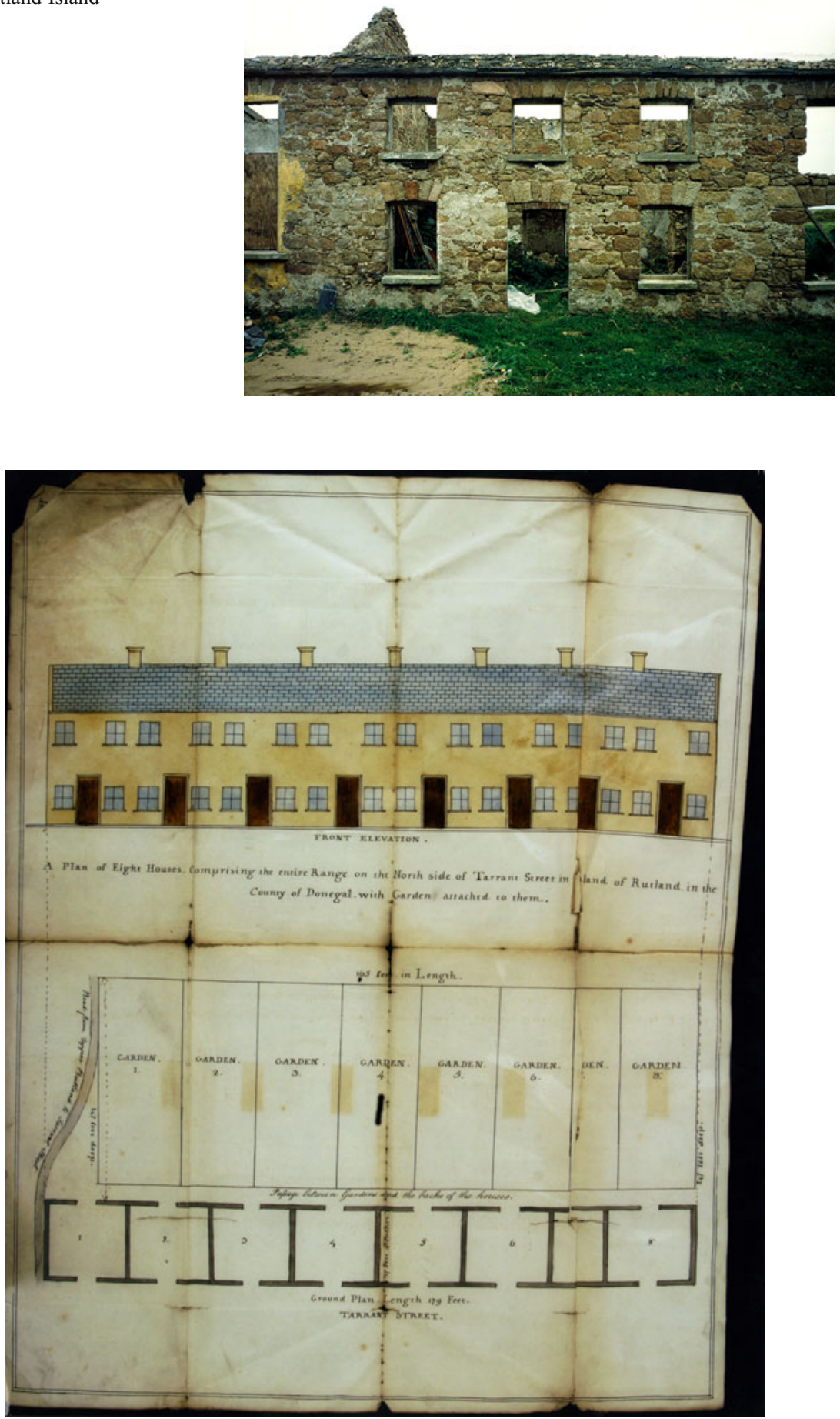

Fig. 3 "A plan of eight houses comprising the entire range on the north side of Tarrant Street in the Island of Rutland in the county of Donegal with garden attached to them." NLI Ms 35,401/3 
brown wooden doors and sash windows. It cannot be considered to be entirely accurate, however, as the lower floor windows are shown as square and of a similar size to those on the first floor (see above). At the back of the houses a narrow passage is depicted beyond which are eight garden plots allotting ca. $282 \mathrm{~m}^{2}$ to each house. To the west is the road north to the fishing station. Unfortunately, the document is undated, but its typography would place it not later than the beginning of the nineteenth century.

On Rathlin Island, Robert Gage established a row of weaver's cottages by 1775 in an attempt to share in the expanding linen industry in the north of Ireland (Gill 1964). The remains of the two-storey weaver's range is constructed of rendered limestone boulders, and features seven bays with windows coupled in three pairs under recessed brick relieving arches (Brett 1974, p. 11). Like Rutland, the upper floor windows are smaller and squarer than those on the ground floor. These cottages were eventually deserted as weavers moved out and settled among the island community (Gage 1995, p. 72). This allowed Gage to re-develop the site, extending the range westwards as the "Manor House," the main residence of his family for the next 200 years. The Manor House features six bays of tall Georgian glazed windows with three molded chimneys above (slightly taller than those on the weavers' building). The entrance is a porch sited to the west end. The door has a Gibbsian surround in red sandstone with an oeilde-boeuf window above dating possibly to ca. 1790 (Brett 1996, p. 86). Gage's residence is described as a "good modern house" in 1838 (Day et al. 1994, p. 131). Extensive remodeling by his son took place in 1816, including expanding the number of rooms, and internal remodeling (Brett 1974, p. 11). Unfortunately, the interior has been heavily amended to incorporate subsequent functions denying any interpretation of how the internal space was originally employed.

\section{Island Homes}

There is no evidence that the weavers Gage had in mind for Rathlin were not Irish, they may have been from south Antrim or the Lagan valley and thus culturally had some similarities with the islanders (though religion may have been a factor). In both Rathlin and Rutland landlords were not about to invest in housing for those from whom they could only expect an average return. The housing built for industrial workers in the islands was in keeping with Georgian tastes in architectural symmetry employing modern materials. Two-storey buildings with slate roofs and red brick, with arched windows and chimneys stood in contrast to single-storey thatched cabins with simple lintels over windows and a smoke hole in the roof. It also introduced new ideas about factory organization and space, that labor should be separated from the home, and rooms should separate the genders and status of those inside.

Vernacular homes in coastal districts of the north and west are single-storey, have a rectangular plan, thatched roof, and gable ends. All the surviving houses are stone built, of locally quarried boulders, with examples built in dry-stone, or using lime mortar and exterior render. They are firmly within the direct entry tradition where the kitchen is directly accessed from outside. One subvariant of the direct entry type house is the byre-dwelling, the name given because animals and humans shared the same living space (Fig. 4). Due to its simple layout this type has been regarded as the 


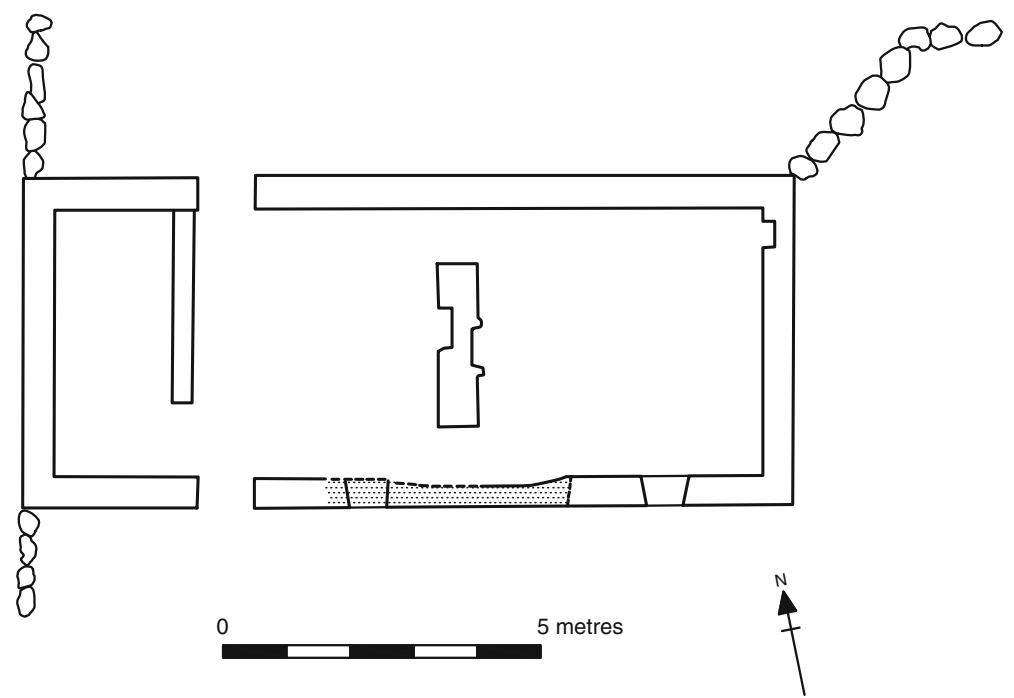

Fig. 4 Plan of vernacular byre dwelling with inserted partition walls, Inishfree Upper, The Rosses

most archaic of houses, and is particularly associated with Donegal (Ó Danachair 1964). The byre in Donegal is evidenced by opposing entries at the "low end" of the kitchen (i.e., the end furthest from the hearth) allowing access from the front and back of the building, with the byre area beyond the doors (animals were tethered to the gable wall) and a transverse open drain for effluent. Improvement in these houses took a number of forms ranging from internal organization to new materials and decorative features. From one-roomed buildings in the late eighteenth-early nineteenth centuries they were increasingly sub-divided, involving the removal of animals by the early twentieth century (Aalen 1997, p. 148). This process of partitioning the living space can be readily detected in many island cottages, with more recent internal walls abutting the original part of the house. As a result most island cottages are divided into three rooms. Sometimes a further room has been appended to the end of the original build, saving the price of a gable wall-about 20 shillings in the mid-nineteenth century (Devon Commission 1847, p. 133). The main internal partition was that between the kitchen and a bedroom behind it. A third room was formed by inserting a second partition wall at the byre end, often adjacent to the door.

The kitchen partition was likely the first major improvement to the interior of homes. Prompted by a move to burning coal (either by necessity or choice) the danger of hot sparks at roof level was a clear danger to thatch. This required the insertion of a flue and the material of choice was red brick. In Rutland, red brick was robbed out of the derelict fishing station in the early nineteenth century. In Rathlin, the insertion of a formal fireplace was accompanied by a decorative hearth of cobbles and the previously earthen floor was paved (Forsythe 2007). This new concern with decorative features seems to accompany or follow the amendment to island hearths. Eventually the thatched roofs of island homes would be replaced by slates. Other elements that became status-symbols in vernacular housing include the clock, porch, and sheeted ceilings. These changes were by no means simultaneous or universal, many were achieved only in the later nineteenth and even early twentieth centuries (Gailey 1984, p. 224). The reason for the slow 
completion of this transition is that tenants were improving their homes without financial aid in an era of widespread poverty and disincentives. These disincentives included the tendency to increase the rent once houses had been improved. For this reason at least some of the changes wrought by tenants in their homes may have been invisible. Excavation work on Rathlin homes found improved, stone-lined drains (French drains) under the floor of one cottage, perhaps an imitation of a form the islanders had encountered on the landlord's property (Forsythe 2007). The situation for the Irish tenant with regard to improvements was summed up in 1847:

in England and Scotland, before a landlord offers a farm for letting, he finds it necessary to provide a suitable farm-house, with necessary farm buildings for the proper management of the farm....he takes upon himself a great part of the burden in keeping buildings in repair during the term; and the rent is fixed with reference to this state of things... In Ireland the case is wholly different...the landlords builds neither dwelling-house nor farm offices, nor puts fences, gates etc. into good order before he lets his land to a tenant... In most cases whatever is done in the way of building or fencing is done by the tenant (Devon Commission 1848, pp. 1122-1123).

\section{Moral Improvement}

Physical improvement of housing was linked to moral and social progress. The physical conditions people lived in were regarded as a reflection of their moral well-being. The state of Irish houses and living conditions were particularly singled out as reinforcing the English view of the barbarity of the Irish (Carroll-Burke 2002, p. 95). As noted above, the building, maintenance and layout of a tenant's house was entirely in his own hands and no large-scale projects were undertaken to improve matters. However, there were other ways to improve the population's moral state. Anglican moral reform movements had extended beyond their own community in the eighteenth century. They targeted the institutions of social life, especially those of the poor: churches, hospitals, schools, libraries and workhouses. These promulgated an individualistic, disciplined and productive community, thereby reinforcing the capitalist ethic (Hayton 1995; Livesey 2004). While these establishments held out a hope of education and health, some institutions of Improvement were also places of dread. John Mitchel, the Young Irelander, made explicit the powerful link between social meaning and public architecture when describing the Glenties workhouse:

a certain new building - the grandest by far that those Rosses people ever sawrearing its accursed gables and pinnacles of Tudor barbarism, and staring boldly with its detestable mullioned windows as if to mock those wretches who still cling to liberty and mud cabins - seeming to them, in their perennial half-starvation, like a Temple erected to the Fates, or like the fortress of Giant Despair, wherinto he draws them one by one, and devours them there (Mitchel 1876, p. 116).

In the eighteenth century these institutions had not yet been founded, but some early efforts at social change were aimed directly at the islanders. In Rathlin Bishop 
Francis Hutchinson had introduced a catechism in Irish as early as 1721 . He had some success building a church, parsonage and charity school, but few conversions (Sneddon 2004). A century later a similar project was undertaken by the Ladies Irish Island Association seeking to educate islanders so they could read the scriptures (Anonymous 1836). In such ways islanders were overtly proselytized. Ultimately, these efforts failed through a lack of institutions to establish discipline as well as resistance from the (mainly Catholic) communities and criticism from New Light Presbyterianism (Livesey 2004, pp. 635-636). At the beginning of the eighteenth century, the Catholic church was technically illegal. By the mid-nineteenth century it was an accepted part of the structures of power in Irish society (Connolly 2001, p. 35). The penal laws, regardless of their debated application, had the effect of reinforcing religious and political loyalties rather than eroding them. They also served an important function in reminding the Catholic populace of social boundaries and their place in Irish life and the crucial fact that the privileged ruling class were of a different, alien creed (Hempton 1996, p. 74). With the end of the penal laws, the quest for Catholic emancipation assumed prime importance. Achieved in 1829, it coincided with a period of renewed evangelical proselytism. With Catholic hopes and confidence in the ascendant and the church taking a more active role in political reform, the movement for Protestant converts encountered a population less amenable to its advances (Connolly 2001, pp. 41-42; Hempton 1996, p. 81).

\section{Material Goods and the Islands}

During archaeological work in the islands artifactual material was recovered by surface collection on Rutland Island (at Conyngham Quay and the gardens behind Tarant Street) underwater survey (in Rutland channel) and on Rathlin excavation at the clachans of Ally Upper and Ally Lower. The ceramics in particular are indicative of the emergence of mass-production and distribution, for example the black-glazed redware fragments of varying sizes found across Rutland. These vessels (colloquially termed "blackware" in Ireland) were in production in Belfast, Newry, Portadown, and Antrim in the late eighteenth century (Westropp 1913). These probably functioned as herring or salt jars in the fishing station, the largest being a fragment recovered from the seabed in front of Conyngham Quay ( $0.46 \mathrm{~m}$ internal diameter at the rim). The ceramic assemblages from Rutland do not betray an obvious division between industrial functions at the quay and domestic wares behind the street. This is not particularly surprising considering the reuse of the industrial buildings as residential homes in the nineteenth century and items of this date are present in the collections. In addition, black-glazed earthenware was produced for both domestic and industrial spheres and this is reflected in the varying size and thickness of vessels. Despite the mix of finds inevitable in a site occupied throughout the period, there are a number of items from the era in which the fishing station was active (1786-1800). These include some of the creamware fragments from the harbor and an example of salt-glazed stoneware from the quay. The latter, a fragment of a plate, represents some of the earliest examples of matched tableware sets, being produced from 1720 to 1805 (Meenan 2004, p. 403). It underlines the new individuality of eating manners with each person assigned their place and dining utensils. At the rear of Tarant Street 
ceramics ranged from refined earthenware, including some blue and white transferprinted items, to heavier black-glazed redware. Glassware is represented by bottle fragments, comprising heavy green glass, prominent punts - some of which have pontil marks. Personal items included many fragments of clay pipes. There were few pipe bowls, but the stems had some interesting features including maker's marks and one marked "DERRY" underlining links between the settlement and the major port of the northwest (Fig. 5). The "Derry" pipes appear to have been in use from the eighteenth to early twentieth centuries, and have been recovered from other Irish contexts as well as excavations at the 1832 Irish-built railroad of Duffy's Cut, Pennsylvania (see e.g., Glassie 1982, p. 138; http://duffyscut.immaculata.edu/Index.htm).

From inside Rathlin homes and a more secure context there is a range of material from the excavated settlements at Ally Upper and Lower. At Ally Upper excavation focused on the kitchen area of a two-roomed cottage. The more recent occupation levels were represented by a mortar floor set on a bed of pebbles. Glassware, stoneware jars, roof slates and the remains of a lamp and griddle were all found in association with the final phase of occupation. Below this was a packed earthen floor showing impressions of straw and associated with a simple, open fire represented by hearth stones and burnt earth (Forsythe 2007). This phase produced a fragment of brown transfer-printed ware dating to the early nineteenth century. Below this a single undecorated fragment of refined earthenware was recovered in association with the eighteenth-century stone-lined drains. The evidence from eighteenth- and early nineteenth-century occupation phases demonstrates that refined tablewares were making their way into island homes (albeit in very small quantities) while their inhabitants were still using the older, open hearth- "polite" goods associated with the consumption of tea appearing before the kitchen interior was improved with chimney and flue. The finds from Ally Lower are predominantly nineteenth century in date and associated with the improved hearth and its decorative surround of cobbling (see above). They include fragments of utilitarian black-glazed redware as well as refined earthenwares with blue and white painted designs.

There are instances of landlords taking direct action to make new commodities available, thus facilitating the new market conditions. For example Lord Hill's store

Fig. 5 Finds from Rutland Island, including (top) glassware and ceramics recovered from Conyngham Quay, and (bottom) clay pipe stem stamped "32" and "DERRY" from the gardens to the rear of Tarant Street

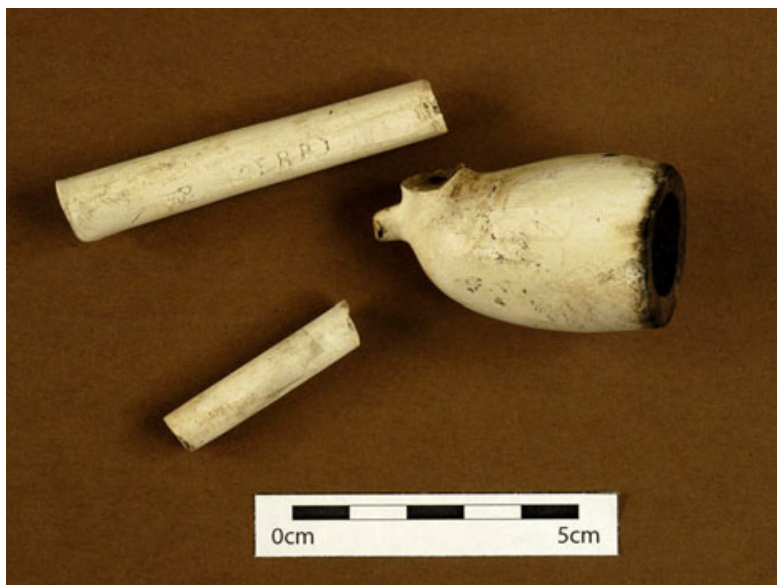


in Bunbeg (to the north of The Rosses) "where all articles required for the consumption of the country are imported" from Dublin, Glasgow, and Liverpool (Hill 1971, p. 45). Items listed in the store include "delft of all kinds" (including tableware, pots, and basins) dinner knives, bottles, and tobacco pipes. Hill claimed that previous to the shop (i.e., before the 1830s) "there was neither hardware nor crockery to be seen in the cabins, but now these things have become quite common" (Hill 1971, pp. 38-40). One building on Rutland is mentioned as a house for a shop-keeper in 1812. Although there is no firm indication it ever operated as such, the finds from across the island show that mass-produced goods were finding their way into the Rutland settlement - probably to meet the material expectations of the new inhabitants. The Rathlin islanders were often paid for kelp with money on their tab in a Ballycastle shop (on the mainland opposite), presumably a general store where a similarly widerange of goods could be obtained (Murphy 1987, p. 72). The above stores were in operation in the nineteenth century, however, it is clear from excavations at Ally and surface collection at Rutland that at least some of this material had made its way to the islands in the eighteenth century.

\section{Changing Routines and Encounters with Consumerism}

By the end of the eighteenth century, the islands were successfully integrated into the commercial world, selling agricultural produce through fairs, making kelp, and growing flax. They benefited from the new market structure, but suffered disproportionately from specialization (e.g., an over-reliance on kelp as a cash crop). The impact of widening commercial networks eventually affected every strata of society. In particular it changed the patterns of consumption. Until the mid-eighteenth century tenants and laborers consumed little beyond tobacco that was not homemade (Dickson 1987, p. 110). Islanders were consuming tobacco and spirits with "no notion of any other necessaries of life," but showed a willingness to adopt, for example, new modes of dress, when exposed to external influences (A. B. 1818, pp. 200-204). The new cash economy and networks presented new commodities to purchase but could also have a limiting effect. One of the most striking changes was in dietary regime. In the later eighteenth century the market demand increased for grain and local consumption fell, as the poor could not afford it and farmers preferred turning it to cash. Equally the market demand for butter caused a shift to buttermilk. The emphasis on tillage and rising population put pressure on the grazing area with the resulting change from cattle to pigs. Most notoriously the population and especially the poorest laborers who benefited less from the economic changes came to rely on the potato (Clarkson 1999).

Life in the home was inevitably affected, tenant housing was increasingly subdivided and new materials appear-brick chimneys, slate roofs, glazed windows, earthen floors replaced with paving, decorative cobbling hinting at a new expressions of interior taste. It is important to emphasize that "improvements" may have been primarily motivated by practical or necessary responses rather than any social agenda. These include the need to erect a chimney to enable coal burning due to a lack of turf on Rathlin. Regardless of the motives, these changes drew islanders deeper into the new commercial world and tied the welfare of their households to the fluctuating commodity prices. 
The mechanism by which the new merchandise was adopted is not well understood nor indeed the wider relationship of social meaning and consumer choice. The paucity of work carried out in Ireland does not constitute even a modest sample of the material culture of this era. Further archaeological excavation of clachans and other forms of settlement occupied in the eighteenth and nineteenth centuries is needed to clarify chronologies and document changing materials in diverse locations and situations. Discerning the motivations, aspirations and meaning of Improvement to the poor and peripheral in society remains fraught with difficulty in both Irish and other contexts (see Tarlow 2007, pp. 160-162). Any perspective offered here therefore is necessarily limited, but even a cursory examination of the islands reveal complex and subtle consumer activity that defy sweeping interpretations. Common adoption propositions relate the role of material goods to identity, in terms of exercising choice as a way to elevate ones social status, imitate others, or differentiate oneself from a particular group (Brewer and Porter 1993, pp. 1-15). In an Irish context this is an especially vexed question - the power structure of Irish society inevitably means that the choice of material culture is regarded as a political act. As a result many archaeologists have tended to view cultural process and consumer choice in the country primarily through the prism of colonialism (e.g., Orser 2005b).

Livesey (2004, p. 639) has underlined the difficulty of relying on social emulation for change when the population is not allowed to fully participate in trade and public life. In areas such as The Rosses there were few sources for social emulation on the scale of a resident landlord's house. New settlements like Rutland with merchants and officials provided the closest encounter with an alternative way of life and material value system. In Rutland, despite incidents of resistance to the settlement, there was a continued islander presence and on abandonment of the fishing station materials were robbed to copy introduced modes in island homes (e.g., red brick window and door surrounds were removed to form chimneys and door surrounds in cottages). Only on Rathlin was the landlord resident for much of the nineteenth century to provide an exemplar for "elite" tastes. In areas of grinding poverty and subsistence emulation of elites was beyond the means of the majority of the population. It is not surprising then that where change occurs it is piecemeal and selective, and may be more a result of imitating affordable alterations to buildings or obtaining goods as others adopt them within the community. New fashions such as the tea drinking became highly popular after the import duties that confined it to a luxury item were abolished in 1784. Such consumption required "polite" tableware to participate in the new ritual, whilst entertaining indoors may have provided the impetus for decorative changes. Arguably consumer choice in this case was exercised in light of neighbors new possessions and practices rather than aping elites. Orser's $(2005 b, 2006)$ work has highlighted the importance of refined tea-drinking wares seemingly at odds with poverty and the threat of eviction in Ballykilcline, Co. Roscommon. Shammas (1990, p. 299) and Klein (1991, p. 83) have similarly noted the relationship between the poor and their choice of ceramics, textiles, and other goods to be complex and seemingly at odds with their means. Social and material imitation was not confined to the impoverished, as landlords of modest means also emulated their social peers. Demonstrating the embrace of the Improvement creed included taking an interest of scientific pursuits, keeping up with estate and architectural fashions and current debates. On Rathlin, this was necessarily on a smaller-scale than large landowners in richer parts of the 
country. Nevertheless, Gage reorganized his estate, experimented with exotic species in his walled garden and built a residence in the modern style (see Barnard 1995, p. 149 for a further example in north Antrim).

\section{Conclusion}

Archaeologists have long recognized that material culture is not indicative only of emulation (e.g., Hall 1992; Leone 1999, p. 19). "Colonial" readings of Ireland have tended to see consumer choice exercised as a rejection or embrace of British goods and therefore ideology. While this model arguably works well for seventeenth century Ireland where settler and native were strongly distinguished by dress, language, religion, building and material traditions; by the nineteenth century, these markers were considerably reduced and the framework less useful. Gradual cultural erosion, adoption, and interaction between the descendants of both Planter and Gael serve to blur distinctions and choices in the new consumer products. This is particularly the case in Ulster where the large planter population had a much wider socioeconomic profile than Protestants in other parts of Ireland, and was by no means confined to the narrow, upper echelons of society. By the nineteenth century the relationship between cultural and political attitudes, material culture and adoption is much more complex. The presence of seemingly elite commodities and materials are as likely to be the products of subverting Improvement as embracing it. In the islands local people took full and enthusiastic advantage of differing tax regimes between Ireland and Britain to engage in smuggling. A number of improved structures on Rathlin (quay, storehouses) were covertly employed to receive and ship smuggled goods, including the luxuries (tobacco, spirits, wine), agricultural products (wool) and manufactured goods (linen). Such fluidity in the use and misuse of the structures (both physical and economic) of Improvement warns against a simple reading of archaeological remains as a static reflection of consumer practice. In addition Irish-made contributions to architecture, furniture, glassware, and ceramics emerge by the end of the eighteenth century. Political radicals within Irish society were by this period encouraging the populace to support Irish-made products regardless of any association with polite society or elites (Powell 2005, p. 70). While the medium may have become depoliticized the message lost none of its potency and some of the goods now produced openly carried emblems and slogans aligning themselves with dissenting viewpoints (see e.g., Hartnett 2004). The radicals emerging in the late eighteenth century were often drawn from the middle ranks of society-this new class contributing to a diversification of goods, services and ideas helped to spread through newspapers and pamphlets subversive opinion and politics. Ironically, material and educational improvements meant to convince the populace of the benefits of established order instead raised expectations and discontent which led to open uprising in the 1790s (Barnard 2008, p. 172). The emergence of a new "middling" class is a major social development of the eighteenth century, indeed increasing social gradation between laborer, cottier, sub-tenant, small tenant farmer, larger graziers, agents, bailiffs, and middle-men is under-appreciated in the overly static colonial model that has focused on an exclusively dualistic notion of rich, landed Protestant elite versus mass of disenfranchised Catholic poor. Historical archaeologists need to afford due 
consideration to class relations across established divisions in Irish society, testing for example whether there are significant differences in the material culture of small tenants in Catholic west Donegal or Presbyterian east Antrim.

The principles of Improvement are repeatedly and explicitly expressed over three centuries, providing a contemporary philosophical framework for understanding the transformation of the Irish landscape and domestic conditions in the later historic era. As such this potent and persistent orthodoxy remains a key foundation for the study of post-medieval archaeology. The importance of Improvement lies not only in its longevity but also its development and application. It could be exploited for seventeenth-century British expansionism, declared a patriotic duty by eighteenthcentury mercantile lobbies and pressed as a moral imperative by nineteenth-century clerics and missionary societies. Improvement precepts and schemes were neither embraced universally, nor adopted in their entirety but the usefulness of the concept remains undiminished as an aspiration, at least in the minds of social elites, for good government, economic productivity, and social well-being. As such it acts as a benchmark for the participation, evolution, and responses of all levels in society. It is tempting within the responses of tenants to see some of the traits identified by postcolonial commentators among the colonized including mimicry, irony, and subversion (Bhabha 1994; Graham 1994). Indeed the islanders display not only selectivity about which elements of the new material culture they incorporate, but also considerable ingenuity in manipulating the system for their own ends. However also evident is the varied regional, social and economic means of the improvers themselves in driving the agenda of Improvement forward. Ultimately the colonial/post-colonial paradigms provide too restrictive a palette for the study of material change within Ireland in this era. Aside from the contentious issue of whether Ireland can be considered truly colonial or indeed post-colonial (see e.g., Graham 1994; Horning 2006, 2007; Kennedy 1993); the discourse of colonialism sits uneasily with emerging Irish material culture in the eighteenth and nineteenth centuries. It was in this era that the country experienced the consumer revolution (see e.g., Courtney 1996; Hall 1992), the affects of which eventually touched all levels in society. In this more competitive and class-conscious world new social stratifications within and between the main confessional groups became more evident. Fuller cognizance of these aspects of capitalism demand attention in future research agendas.

Acknowledgments I wish to thank my colleagues Colin Breen and Rosemary McConkey, the Northern Ireland Environment Agency, National Library of Ireland, and The Heritage Council.

\section{References}

A. B. (1818). An account of the customs, manners and dress of the inhabitants of the Rosses. In Walker, J. C. (ed.), Historical Memoirs of the Irish Bards. Dublin.

Aalen, F. H. A. (1997). Buildings. In Aalen, F. H. A., Whelan, K., and Stout, M. (eds.), Atlas of the Rural Irish Landscape, Cork University Press, Cork, pp. 145-179.

Andrews, J. H. (1956). A note on the later history of the Irish charcoal iron industry. The Journal of the Royal Society of Antiquaries of Ireland 86: 217-219.

Anonymous. (1836). Letters descriptive of the present state of islands around Ireland. Edinburgh.

Barnard, T. C. (1975). Cromwellian Ireland. English Government and Reform in Ireland 1649-1660, Oxford University Press, Oxford. 
Barnard, T. C. (1981). Fishing in seventeenth-century Kerry: the experience of Sir William Petty. Journal of the Kerry Archaeological and Historical Society 14: 14-25.

Barnard, T. C. (1982). Sir William Petty as Kerry ironmaster. Proceedings of the Royal Irish Academy 82: $1-32$.

Barnard, T. C. (1995). Improving clergymen, 1660-1760. In Ford, A., McGuire, J., and Milne, K. (eds.), As By Law Established. The Church of Ireland Since the Reformation, The Lilliput Press, Dublin, pp. 136-151.

Barnard, T. C. (2001). "Grand metropolis" or "The anus of the world"? The cultural life of eighteenthcentury Dublin. In Clark, P., and Gillespie, R. (eds.), Two Capitals: London and Dublin 1500-1840, Oxford University Press, Oxford, pp. 185-210.

Barnard, T. C. (2008). Improving Ireland? Projectors, Prophets and Profiteers, 1641-1786, Four Courts Press, Dublin.

Bell, J. (1984). A contribution to the study of cultivation ridges in Ireland. The Journal of the Royal Society of Antiquaries of Ireland 114: 80-97.

Bell, J., and Watson, M. (1986). Irish Farming. Implements and Techniques 1750-1900, John Donald Publishers, Edinburgh.

Bhabha, H. K. (1994). The Location of Culture, Routledge, London.

Boate, G. (1726). The Natural History of Ireland, George Grierson, Dublin.

Brett, C. E. B. (1974). Historic Buildings, Groups of Buildings, Areas of Architectural Importance in the Island of Rathlin, Ulster Architectural Heritage Society, Belfast.

Brett, C. E. B. (1996). Buildings of County Antrim, Ulster Architectural Heritage Society and Ulster Historical Foundation, Belfast.

Brewer, J., and Porter, R. (1993). Consumption and the World of Goods, Routledge, London.

Buchanan, R. H. (1973). Field systems of Ireland. In Baker, A. R. H., and Butlin, R. A. (eds.), Studies of Field Systems in the British Isles, Cambridge University Press, Cambridge, pp. 580-618.

Busteed, M. (2001). Sir James Caldwell, c.1720-84: an Anglo-Irish landlord in an age of improvement. Irish Studies Review 9(3): 317-329.

Carroll-Burke, P. (2002). Material designs: engineering cultures and engineering states-Ireland 16501900. Theory and Society 31: 75-114.

Clarkson, L. (1999). The modernisation of the Irish Diet, 1740-1920. In Davis, J. (ed.) Rural change in Ireland, The Institute of Irish Studies, Queens University Belfast, Belfast, pp. 32-44.

Commission, D. (1847). Digest of Evidence Taken Before her Majesty's Commissioners of Inquiry into the State of the Law and Practice in Respect to the Occupation of Land in Ireland. Part I, Alexander Thom, Dublin.

Commission, D. (1848). Digest of Evidence Taken Before her Majesty's Commissioners of Inquiry into the State of the Law and Practice in Respect to the Occupation of Land in Ireland. Part II, Alexander Thom, Dublin.

Connolly, S. J. (2001). Priests and People in Pre-Famine Ireland, 1780-1845, Four Courts Press, Dublin.

Courtney, P. (1996). In small things forgotten: the Georgian world view, material culture and the consumer revolution. Rural History 7(1): 87-95.

Crawford, W. H., and Trainor, B. (1978). Aspects of Irish Social History 1750-1800, HMSO, Belfast.

Cullen, L. M. (1990). Catholic social classes under the penal laws. In Power, T. P., and Whelan, K. (eds.), Endurance and Emergence. Catholics in Ireland in the Eighteenth Century, Irish Academic Press, Dublin, pp. 57-84.

Dalglish, C. (2003). Rural Society in the Age of Reason. An Archaeology of the Emergence of Modern Life in the Southern Scottish Highlands, Kluwer Academic/Plenum, New York.

Day, A., McWilliams, P. and Dobson, N. (1994). Ordnance Survey Memoirs of Ireland. Parishes of County Antrim IX. North Antrim Coast and Rathlin, Institute of Irish Studies, Queens University Belfast, Belfast.

Dickson, D. (1987). New Foundations: Ireland 1660-1800, Helicon, Dublin.

Dowling, M. W. (1999). Tenant Right and Agrarian Society in Ulster 1600-1870, Irish Academic Press, Dublin.

Drayton, R. (2000). Nature's Government: Science, Imperial Britain, and the "Improvement" of the World, Yale University Press, New Haven.

Dublin Evening Post. (1785). Untitled. March 15.

Dubordieu, J. (1812). Statistical Survey of the County of Antrim, vol. II, Graisbery and Campbell, Dublin. Evans, E. E. (1977). Irish Heritage, Dundalgan Press, Dundalk.

Feehan, J. (2003). Farming in Ireland: History, Heritage and Environment, University College Dublin Faculty of Agriculture, Dublin. 
Feehan, J., and O'Donovan, G. (1996). The Bogs of Ireland: An Introduction to the Natural, Cultural and Industrial Heritage of Irish Peatlands, Environmental Institute, University College Dublin, Dublin.

Forsythe, W. (2006). The archaeology of the kelp industry in the northern islands of Ireland. International Journal of Nautical Archaeology 35: 218-229.

Forsythe, W. (2007). On the edge of improvement: Rathlin Island and the modern world. International Journal of Historical Archaeology 11: 221-240.

Forsythe, W. (2012). Improving landlords and planned settlements in eighteenth-century Ireland: William Burton Conygham and the fishing station on Inis Mhic an Doirn, Co. Donegal. Proceedings of the Royal Irish Academy 112C: 1-32.

Forsythe, W., and McConkey, R. (2012). Rathlin Island: An Archaeological Survey of a Maritime Landscape, TSO, Belfast.

Fourth report of the commissioners of the Irish fisheries of their proceedings for the year 1822. (1823). Sessional papers 10. HMSO, London.

Gage, C. (1995). A History of the Island of Rathlin Island, J. Margaret Dickson, Coleraine.

Gailey, A. (1984). Rural Houses of the North of Ireland, John Donald, Edinburgh.

Gill, C. (1964). The Rise of the Irish Linen Industry, Clarendon Press, Oxford.

Glassie, H. H. (1982). Passing the Time in Ballymenone: Culture and History of an Ulster Community, University of Pennsylvania Press, Philadelphia.

Graham, C. (1994). "Liminal spaces": post-colonial theories and Irish culture. The Irish Review 16: $29-43$.

Hall, M. (1992). Small things and the mobile, conflictual fusion of power, fear, and desire. In Yentsch, A. E., and Beaudry, M. C. (eds.), The Art and Mystery of Historical Archaeology. Essays in Honor of James Deetz, CRC Press, Boca Raton, pp. 373-398.

Hamilton, W. (1839). Letters Concerning the Northern Coast of the County of Antrim; Containing Observations on the Antiquities, Manners and Customs of that Country, Samuel Hart, Coleraine.

Hartnett, A. (2004). The politics of the pipe: clay pipes and tobacco consumption in Galway, Ireland. International Journal of Historical Archaeology 8: 133-147.

Hayton, D. (1995). Did Protestantism fail in early eighteenth-century Ireland? Charity schools and the enterprise of religious and social transformation c.1690-1730. In Ford, A., McGuire, J., and Milne, K. (eds.), As by Law Established: The Church of Ireland Since the Reformation, Lilliput Press, Dublin, pp. 166-186.

Hempton, D. (1996). Religion and Political Culture in Britain and Ireland, Cambridge University Press, Cambridge.

Hill, G. (1971). Facts from Gweedore, Institute of Irish Studies, Queens University Belfast, Belfast.

Horning, A. J. (2006). Archaeology, conflict and contemporary identity in the north of Ireland: implications for theory and practice in comparative archaeologies of colonialism. Archaeological Dialogues 13: 183-200.

Horning, A. J. (2007). Cultures of contact, cultures of conflict? Identity construction, colonialist discourse, and the ethics of archaeological practice in Northern Ireland. Stanford journal of archaeology 5: 107-133.

Hutton, A. W. (1892). Arthur Young's Tour in Ireland (1776-1779), vol. 2, George Bell, London.

Johnson, M. H. (1996). An archaeology of Capitalism, Blackwell, Oxford.

Johnson, M. H. (1997). Rethinking houses, rethinking transitions: of vernacular architecture, ordinary people and everyday culture. In Gaimster, D., and Stamper, P. (eds.), The Age of Transition: The Archaeology of English Culture 1400-1600, Oxbow, Oxford, pp. 145-155.

Jupp, P. (1970). Genevese exiles in County Waterford. Journal of the Cork Archaeological and Historical Society 75: 29-35.

Kelly, J. (1985). William Burton Conyngham and the north-west fishery of the eighteenth century. The Journal of the Royal Society of Antiquaries of Ireland 115: 64-85.

Kelly, J. (1986). Prosperous and Irish industrialisation in the late eighteenth century. Journal of the Co. Kildare Archaeological Society 16(5): 441-467.

Kennedy, L. (1993). Modern Ireland: post-colonial society or post-colonial pretensions? The Irish Review 13: 107-121.

Klein, T. H. (1991). Nineteenth-century ceramics and models of consumer behavior. Historical Archaeology 25(2): 77-91.

Lambert, J. (1845). Agricultural Suggestions to the Proprietors and Peasantry of Ireland, William Curry, Jr, Dublin.

Leone, M. (1999). Setting some terms for historical archaeologies of capitalism. In Leone, M., and Potter, P. B. (eds.), Historical Archaeologies of Capitalism, Kluwer Academic/Plenum, New York, pp. 3-20.

Livesey, J. (2004). The Dublin Society in eighteenth-century Irish political thought. The Historical Journal 47(3): 615-640.

Longfield, A. (1966-67). Prosperous 1776-1798. Journal of the Co. Kildare Archaeological Society 14 (2): $212-231$ 
Ludlow, C. G. (1989). An outline of the history of the salt industry in Ireland. In Schofield, R. B. (ed.), The History of Technology, Science, and Society, 1750-1914, University of Ulster, Coleraine, pp. 1-18.

MacSuibhne, B. (1995). Agrarian improvement and social unrest: Lord George Hill and the Gaoth Dobhair sheep war. In Nolan, W., Ronayne, L., and Dunlevy, M. (eds.), Donegal History and Society, Geography Publications, Dublin, pp. 547-582.

Magennis, E. (2002). "A land of milk and honey": the physico-historical society, improvement and the surveys of mid-eighteenth-century Ireland. Proceedings of the Royal Irish Academy 102: 199-217.

Mason, T. H. (1936). The Islands of Ireland, B. T. Batsford, London.

McCourt, D. (1954). Infield and outfield in Ireland. The Economic History Review 11: 369-376.

McCourt, D. (1955). The rundale system in Donegal its distribution and decline. Donegal Annual 3: 47-60.

McCourt, D. (1971). The dynamic quality of Irish rural settlement. In Buchanan, R. H., Jones, E., and McCourt, D. (eds.), Man and His Habitat, Essays Presented to Emyr Estyn Evans, Routledge and Kegan Paul, London, pp. 126-164.

McCourt, D. (1973). Innovation diffusion in Ireland: an historical case study. Proceedings of the Royal Irish Academy 73(1): 1-19.

McParlan, J. (1802). Statistical survey of the County of Donegal, Graiberry and Campbell, Dublin.

Meenan, R. (2004). Pottery of the late medieval and post-medieval periods. In Fitzpatrick, E., O’Brien, M., and Walsh, P. (eds.), Archaeological Investigations in Galway City, 1987-1998, Wordwell, Bray, pp. 376-404.

Mitchel, J. (1876). The Last Conquest of Ireland, Cameron Ferguson, Glasgow.

Murphy, M. J. (1987). Rathlin: Island of Blood and Enchantment, Dundalgan Press, Dundalk.

NLI (National Library of Ireland) Conyngham collection 53, Ms35, Dublin.

Ó Danachair, C. (1964). The combined byre-and-dwelling in Ireland. Folk Life 2: 58-75.

Ó Gráda, C. (1994). Ireland a New Economic History 1780-1939, Clarendon Press, Oxford.

Orser Jr., C. E. (2005a). Symbolic violence, resistance and the vectors of improvement in early nineteenthcentury Ireland. World Archaeology 37: 392-407.

Orser Jr., C. E. (2005b). The material implications of colonialism in early nineteenth-century Ireland. In McDonough, T. (ed.), Was Ireland a Colony? Irish Academic Press, Dublin, pp. 66-83.

Orser Jr., C. E. (2006). Unearthing Hidden Ireland: Historical Archaeology at Ballykilcline, Co. Roscommon, Wordwell, Bray.

Powell, M. J. (2005). The Politics of Consumption in Eighteenth-Century Ireland, Palgrave Macmillan, Hampshire.

PRONI (Public Record Office of Northern Ireland). Arthur Young papers. T/3469/9. Belfast.

Proudfoot, V. B. (1959). Clachans in Ireland. Gwerin 2(3): 110-122.

Proudfoot, L. J. (1993). Spatial transformation and social agency: property, society and improvement, c.1700 to c.1900. In Graham, B. J., and Proudfoot, L. J. (eds.), An Historical Geography of Ireland, Academic Press, London, pp. 219-257.

Ramsay, W. (1918). The Life and Letters of Joseph Black, M.D, Constable, London.

Shammas, C. (1990). The Pre-Industrial Consumer in England and America, Clarendon, Oxford.

Sneddon, A. (2004). "Darkness must be expell'd by letting in the light": Bishop Francis Hutchinson and the conversion of Irish Catholics by means of the Irish language, c.1720-1724. Eighteenth-Century Ireland 19: $37-55$.

Tarlow, S. (2007). The Archaeology of Improvement in Britain, 1750-1850, Cambridge University Press, Cambridge.

The Census of Ireland for the year 1851. (1856). Alexander Thom and Sons, Dublin.

Trench, C. E. F. (1985). William Burton Conyngham (1733-1796). The Journal of the Royal Society of Antiquaries of Ireland 115: 40-63.

Ua Cnaímhsí, P. (2000). A voice from the past: the Inishfree letters. Donegal Annual 52: 53-56.

Wall, M. (1989). The rise of a Catholic middle class in eighteenth-century Ireland. In O'Brien, G. (ed.), Catholic Ireland in the Eighteenth Century: Collected Essays of Maureen Wall, Geography Publications, Dublin, pp. 73-92.

Westropp, M. S. D. (1913). Notes on the pottery manufacture in Ireland. Proceedings of the Royal Irish Academy 32(1): 1-27.

Whelan, K. (1995). Pre and post famine landscape change. In Póirtéir, C. (ed.), The Great Irish Famine, Mercier Press, Cork, pp. 19-33.

Whelan, K. (1997). The modern landscape. In Aalen, F. H. A., Whelan, K., and Stout, M. (eds.), Atlas of the Rural Irish Landscape, Cork University Press, Cork.

Wood, H. (1934). Sir William Petty and his Kerry estates. The Journal of the Royal Society of Antiquaries of Ireland 64: 22-40.

Wood, E. M. (2002). The Origin of Capitalism: A Longer View, Verso, London. 